\title{
ON THE IMPACT OF BORESCOPE CAMERA AIR PURGE ON DWPF MELTER OFF-GAS FLAMMABILITY (U)
}

A. S. Choi

January 2004

Immoblization Technology Section Savannah River Technology Center Aiken, SC 29808 
This document was prepared in conjunction with work accomplished under Contract No. DE-AC09-96SR18500 with the U. S. Department of Energy.

\section{DISCLAIMER}

This report was prepared as an account of work sponsored by an agency of the United States Government. Neither the United States Government nor any agency thereof, nor any of their employees, makes any warranty, express or implied, or assumes any legal liability or responsibility for the accuracy, completeness, or usefulness of any information, apparatus, product or process disclosed, or represents that its use would not infringe privately owned rights. Reference herein to any specific commercial product, process or service by trade name, trademark, manufacturer, or otherwise does not necessarily constitute or imply its endorsement, recommendation, or favoring by the United States Government or any agency thereof. The views and opinions of authors expressed herein do not necessarily state or reflect those of the United States Government or any agency thereof.

This report has been reproduced directly from the best available copy.

Available for sale to the public, in paper, from: U.S. Department of Commerce, National Technical Information Service, 5285 Port Royal Road, Springfield, VA 22161, phone: (800) 553-6847, fax: (703) 605-6900

email: orders@ntis.fedworld.gov

online ordering: http://www.ntis.gov/help/index.asp

Available electronically at http://www.osti.gov/bridge

Available for a processing fee to U.S. Department of Energy and its contractors, in paper, from: U.S. Department of Energy, Office of Scientific and Technical Information, P.O. Box 62, Oak Ridge, TN 37831-0062,

phone: (865)576-8401,

fax: (865)576-5728

email: $\underline{\text { reports@ adonis.osti.gov }}$ 
Key Words: DWPF, Melter, Borescope, Air Purge, Off-Gas Flammability

Retention: Permanent

\section{ON THE IMPACT OF BORESCOPE CAMERA AIR PURGE ON DWPF MELTER OFF-GAS FLAMMABILITY (U)}

A. S. Choi

January 2004

Immoblization Technology Section Savannah River Technology Center Aiken, SC 29808

Prepared for the U.S. Department of Energy Under Contract Number DEAC09-96SR18500

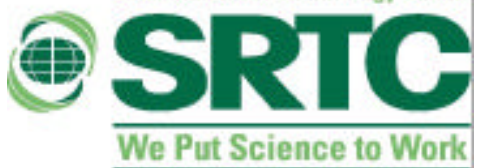


This page was intentionally left blank 


\section{EXECUTIVE SUMMARY}

DWPF Engineering personnel requested that a new minimum backup film cooler air flow rate, which will meet the off-gas safety basis limits for both normal and seismic sludge-only operations, be calculated when the air purge to the borescope cameras is isolated from the melter [HLW/DWPF/TTR-03-0015]. Specifically, it was requested that the latest E-7 calculations [X-CLC-S-00097 \& X-CLC-S-00124] which were used to set the off-gas flammability safety bases for the sludge batch 2 and 3 feeds be revised, while maintaining all other process variables affecting off-gas flammability such as total organic carbon (TOC), feed rate, melter air purges, and vapor space temperature at their current respective maximum or minimum limits.

Before attempting to calculate the new minimum backup film cooler air flow, some of the key elements of the combustion model were reviewed first, and it was determined that the current minimum backup film cooler air flow of $233 \mathrm{lb} / \mathrm{hr}$ is adequate enough to satisfy the off-gas flammability safety bases for both normal and seismic operations in the absence of any borescope camera air purge. It is, therefore, concluded that there is no need to revise the reference E-7 calculations. This conclusion is in essence based on the fact that the current minimum backup film cooler air flow was set to satisfy the minimum combustion air requirement under the worst-case operating scenario involving a design basis earthquake during which all the air purges not only to the borescope cameras but to the seal pot are presumed to be lost due to pipe ruptures. The minimum combustion air purge is currently set at $150 \%$ of the stoichiometric air flow required to combust 3 times the normal flow of flammable gases. The DWPF control strategy has been that $100 \%$ of the required minimum combustion air is to be provided by the controlled air purge through the backup film cooler alone (FIC3221B).

Furthermore, any backup film cooler air supplied in excess of the required minimum will not necessarily improve the combustion efficiency and, at a given total melter air purge to FIC322A, the air flow not directed to the borescope cameras will be sent to the primary film cooler. Therefore, the presumed loss of borescope camera air purge should not adversely impact either the melter combustion efficiency or the off-gas flammability downstream of the melter, as long as the minimum combustion air requirement is met at a fixed total melter air purge. To ensure that this is indeed the case under all possible operating modes, a total of nine different air purge scenarios were considered in this work, and it was checked if the calculated total air purge into the vapor space for each case was equal to or greater than the required minimum combustion air flow. The results thus obtained are summarized in this report along with the discussions on some of the key characteristics of the combustion model. 


\section{TABLE OF CONTENTS}

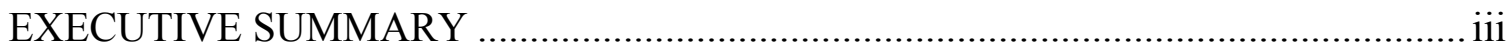

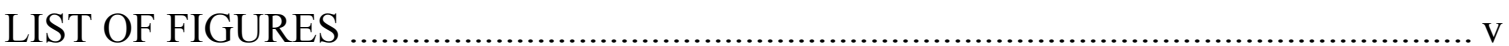

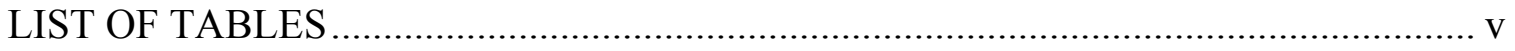

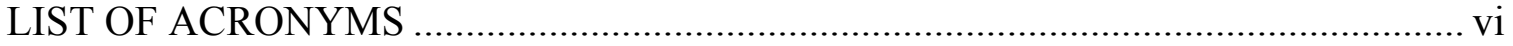

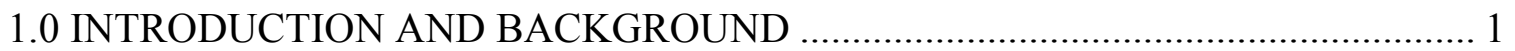

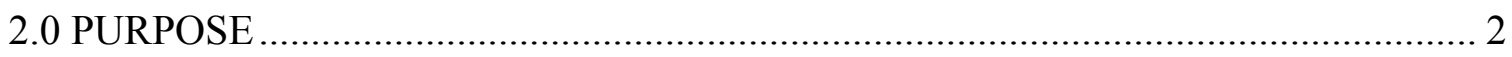

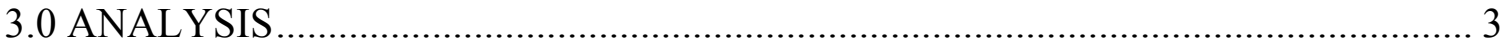

3.1 Combustion Model ................................................................................... 3

3.2 Minimum Combustion Air .......................................................................... 4

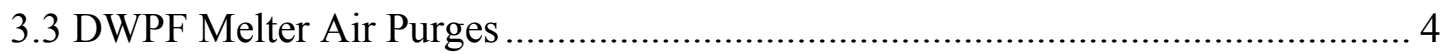

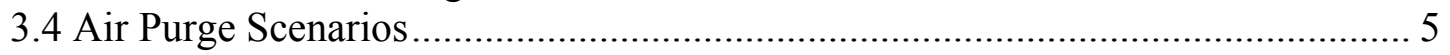

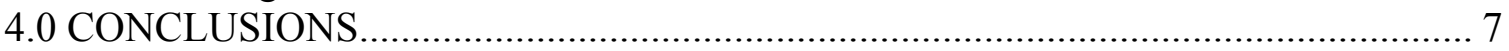

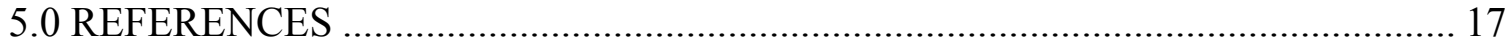




\section{LIST OF FIGURES}

Figure 1. Baseline DWPF Melter Air Purges during Normal Operation with Two Borescope Cameras.

Figure 2. DWPF Melter Air Purges during Normal Operation with

One Borescope Camera.....

Figure 3. DWPF Melter Air Purges during Normal Operation with

No Borescope Camera.

Figure 4. Minimum DWPF Melter Air Purges during Normal Operation with Two Borescope Cameras.

Figure 5. Minimum DWPF Melter Air Purges during Normal Operation with One Borescope Camera.

Figure 6. Minimum DWPF Melter Air Purges during Normal Operation with No Borescope Camera.

Figure 7. Minimum DWPF Melter Air Purges during Seismic Operation with

Two Borescope Cameras.

Figure 8. Minimum DWPF Melter Air Purges during Seismic Operation with

One Borescope Camera. 15

Figure 9. Minimum DWPF Melter Air Purges during Seismic Operation with No Borescope Camera.

\section{LIST OF TABLES}

Table 1. Empirical First-Order Kinetic Parameters for Vapor Space Combustion. 3

Table 2. Effects of Melter Operation and Borescope Camera Air Purge on Combustion and Dilution Air Flows. 


\section{LIST OF ACRONYMS}

DBE

DWPF

GPM

LFL

OGCT

PLA

RO

$\mathrm{SB}$

SGM

TOC

TSR design basis earthquake

Defense Waste Processing Facility

gallons per minute

lower flammability limit

off-gas condensate tank

plant air

restricting orifice

sludge batch

Scale Glass Melter

total organic carbon

Technical Safety Requirements 


\subsection{INTRODUCTION AND BACKGROUND}

The off-gas flammability in the DWPF melter system is determined primarily by: (1) total organic carbon (TOC) in the feed, (2) feed rate, (3) air flows for combustion and cooling, (4) melter vapor space temperature, and (5) off-gas surges. In essence, all these variables except off-gas surges are controlled either by the choice of flowsheet or by the operator, and their impact on the off-gas flammability is interdependent. For example, when the TOC level is increased at fixed air flows, the vapor space temperature would have to be increased by reducing the feed rate in order to maintain a comparable concentration of flammable gases in the melter exhaust. Likewise, when the air flows are reduced at a fixed TOC level, the melter vapor space temperature would have to be increased by reducing the feed rate accordingly.

Two computer models have been used to describe this interdependency and further to set the operating limits for these variables in the form of feed interlocks and technical safety requirements (TSR). ${ }^{1,2}$ The first model, called the 4-stage cold cap model, describes the chemistry of cold cap reactions thermodynamically and predicts the compositions of both calcine gases and glass from a given feed composition. The composition of calcine gases is then used as the input to the second model, called the MOG dynamics model, which predicts the transient behavior of the DWPF melter off-gas system, including the off-gas flammability, under a variety of upset scenarios. One upset scenario most often used in the safety basis analysis is off-gas surges.

Off-gas surges occur mainly due to the cold cap instabilities that are inherent to the slurry feeding operation. Although the feed chemistry is known to contribute significantly to offgas surges, the frequency and magnitude of surges are in essence both uncontrollable and unpredictable. In general, two types of off-gas surges are seen in slurry-fed melters. Steam surges occur as the boiling water layer occasionally falls into the crevices of the cold cap or flows over the edges of the cold cap, thereby coming in contact with the melt surface. The resulting steam surges can pressurize the melter considerably and, therefore, are responsible for the bulk of severe pressure transients that propagate throughout the off-gas system. The non condensable surges occur as the calcine gases that have been accumulating within the cold cap finally build up enough pressure to be released through the weak points or temporary openings of the cold cap.

The bounding magnitudes of both condensable and non condensable surges were derived from available pilot melter data, ${ }^{3,4}$ and DWPF has selected abnormal melter off-gas flows of 3 times (3X) and 7 times ( $7 \mathrm{X})$ normal as the design basis off-gas flows for the flammability and pressure control purposes, respectively. ${ }^{5}$ Specifically, a $3 \mathrm{X}$ off-gas surge lasting 8 minutes with an average intensity of $2.25 \mathrm{X}$ normal during the first 1 minute has been chosen to represent the baseline process upset for establishing the operating bounds of TOC, air flow and vapor space temperature using the two process models mentioned above. Currently, the DWPF melter is in operation with the TSR limits and feed interlocks set based on the following theoretical limits to ensure a full compliance with the off-gas flammability safety bases for both normal and seismic operations with the sludge-only feed: 
- $\quad$ TOC - the maximum limit is set at 18,916 ppm. ${ }^{6}$ The carbon makeup for this TOC limit is as follows: 16,001 ppm formate, 2,426 ppm coal, and $489 \mathrm{ppm}$ free formic.

- Feed rate - neither an interlock nor a TSR limit exists on the maximum feed rate. Instead, the system is protected from the overfeeding of up to $1.5 \mathrm{GPM}$ by the feed interlock on the minimum vapor space temperature, TI4085D. ${ }^{7}$

- Backup film cooler air purge (FIC3221B) - the theoretical minimum is $230 \mathrm{lb} / \mathrm{hr}$ at the TOC limit of $18,916 \mathrm{ppm} .{ }^{6}$ This is $10 \mathrm{lb} / \mathrm{hr}$ higher than the theoretical minimum set earlier for the coupled operation at $0.9 \mathrm{GPM}^{8}{ }^{8}$ Nominally, it is set at $340 \mathrm{lb} / \mathrm{hr}$.

- Total melter air purge (FIC3221A) - the theoretical minimum is $900 \mathrm{lb} / \mathrm{hr} .{ }^{9}$ It is nominally set at $1,070 \mathrm{lb} / \mathrm{hr}$.

- Minimum vapor space temperature - the theoretical minimum is $460{ }^{\circ} \mathrm{C}$, as indicated by TI4085D. ${ }^{9}$

The design basis $3 \mathrm{X}$ off-gas surge was simulated recently at the theoretical limits just given. ${ }^{6}$ The simulation results showed that the peak concentration of flammable gases in the off-gas condensate tank (OGCT) would be just under the safety basis limit of $60 \%$ of the lower flammability limit (LFL) for normal sludge-only operation, while for seismic operation, the predicted maximum off-gas flammability was well below the safety basis limit of $95 \%$ of the LFL. Although not explicitly stated in the reference calculation, ${ }^{6}$ both East and West borescope cameras were assumed to be fully operational, as they had been in all previous calculations. $^{2,7-9}$ Half of the air purge provided to these borescope cameras ends up in the melter vapor space and, therefore, is used as part of the combustion air. A concern is then if the safety basis limits, particularly that for the normal operation, would still be met, when the air purge to the borescope cameras were isolated from the melter.

\subsection{PURPOSE}

Per the technical task request from DWPF engineering personnel, ${ }^{10}$ the purpose of this work was to calculate a new minimum backup film cooler air flow, which will meet the off-gas sludge-only safety basis limits during a $3 \mathrm{X}$ off-gas surge for both normal and seismic operations, when the air purge to both borescope cameras is isolated from the melter. The remaining four variables listed above that affect off-gas flammability are assumed to be maintained at their specified maximum or minimum values. It was further requested that the respective E-7 calculations for the SB2 and SB3 flowsheet be revised, as necessary. ${ }^{6,9}$ 


\subsection{ANALYSIS}

Before carrying out full-blown model runs to calculate a new minimum backup film cooler air flow, some of the key elements of the combustion model were reviewed first to scope out the impacts that the removal of air purge to the borescope cameras would have on the off-gas flammability. It turns out that satisfying the pre-requisite model requirement on the minimum combustion air is essential to achieving the target combustion efficiency, and any additional air flow above this minimum does not necessarily increase the combustion efficiency. The focus of this work was then put on determining if the minimum combustion air requirement is met under a variety of air purge scenarios.

\subsection{Combustion Model}

The two major flammable species entering the vapor space are $\mathrm{CO}$ and $\mathrm{H}_{2}$ and their oxidation reactions are set in the model to follow the apparent first-order kinetics:

$$
-r=k_{o} \exp \left(-E_{a} / R T\right) C
$$

where $-r$ is the reaction rate in $1 b m o l e / \mathrm{ft}^{3} / \mathrm{sec}, \mathrm{k}_{\mathrm{o}}$ the pre-exponential factor in $1 / \mathrm{sec}, \mathrm{E}_{\mathrm{a}}$ the activation energy in Btu/lbmole, $\mathrm{R}$ the gas constant, $\mathrm{T}$ the gas temperature in $\mathrm{K}$, and $\mathrm{C}$ the concentration of $\mathrm{CO}$ or $\mathrm{H}_{2}$ in 1 bmole $/ \mathrm{ft}^{3}$. The first-order kinetic parameters of $\mathrm{CO}$ and $\mathrm{H}_{2}$ oxidation that were found to best fit the DWPF Scale Glass Melter Campaign 9 (SGM-9) data are shown in Table $1 ;^{11,12}$ these empirical kinetic parameters have been validated against smaller-scale melter data. ${ }^{1}$

Table 1. Empirical First-Order Kinetic Parameters for Vapor Space Combustion.

\begin{tabular}{||c|c|c|c||}
\hline \hline & $\begin{array}{c}\mathrm{k}_{\mathrm{o}} \\
(1 / \mathrm{sec})\end{array}$ & $\begin{array}{c}\mathrm{E}_{\mathrm{a}} \\
(\text { Btu/lbmole })\end{array}$ & $\mathrm{R}^{2}$ \\
\hline $\mathrm{CO}$ & 1,759 & 22,192 & 0.845 \\
\hline $\mathrm{H}_{2}$ & $2.795 \mathrm{E} 7$ & 38,940 & 0.999 \\
\hline
\end{tabular}

It is important to note that Eq. (1) contains no oxygen term, since it was assumed that the air flow would be maintained in sufficient excess of the stoichiometric requirement; during the SGM-9 run, air was supplied at least $140 \%$ in excess of the stoichiometric requirement, excluding the air inleakage, for the predicted fuel composition from the formic acid flowsheet based coupled feed. ${ }^{13}$ The implication of this is that once the minimum combustion air requirement is set for the model, any air flow provided in excess of this minimum will not affect the combustion efficiency. In fact, any air flow provided in substantial excess of this minimum will only adversely affect the combustion efficiency by lowering both the gas residence time and the vapor space temperature. Unless the initial vapor space temperature is too low for any combustion to occur, the degree of reduced combustion efficiency due to the excessive air flow would be more than enough to offset any positive contribution it makes downstream as a diluent. 


\subsection{Minimum Combustion Air}

In typical industrial applications, the air flow is maintained at $120 \%$ of the stoichiometric requirement to overcome non ideal gas mixing in the combustion chamber. For the DWPF applications, two additional conservative measures have been introduced in determining the minimum combustion air requirement. First, the stoichiometric air requirement was set based on 3 times the normal flow of flammable gases to account for the baseline $3 \mathrm{X}$ off-gas surge. Second, the minimum combustion air flow was then set at $150 \%$ of this stoichiometric air to account for the fact that the DWPF melter was not designed to be an efficient combustor.

The required minimum combustion air thus depends directly on both the feed rate and the extent to which the combustible gases are oxidized in the cold cap prior to entering the vapor space. It was shown in the earlier E-7 calculation that the minimum combustion air required during the SB3 campaign at 1.5 GPM feed rate and 18,916 ppm TOC is $230 \mathrm{lb} / \mathrm{hr}^{6}{ }^{6}$ This is the minimum air purge into the melter vapor space, not including the air inleakage, which must be maintained under all operating conditions. This minimum air purge for the SB3 feed is slightly higher than $220 \mathrm{lb} / \mathrm{hr}$, which was set earlier for the coupled feed at $0.9 \mathrm{GPM}{ }^{8}$

It should be noted that the minimum combustion air flow thus set for the DWPF melter is still somewhat higher than the optimum air flow for combustion. This is because the minimum combustion air flow was set, as if the baseline $3 \mathrm{X}$ surge selected for the flammability control would continue indefinitely at its peak intensity, although it was designed to last for a total of 8 minutes with the $3 \mathrm{X}$ normal peak occurring only at the 1 minute mark. This approach was taken to prevent the system from ever becoming air deficient and the combustion efficiency from deteriorating rapidly at the peak of a surge. Thus, the current minimum combustion air flow was not set for the optimum combustion efficiency; its setting was rather dictated by the safety considerations, and any decision to increase the total air purge into the vapor space above this minimum must be made judiciously.

\subsection{DWPF Melter Air Purges}

The air purges to the DWPF melter system are provided through: (1) the primary film cooler, (2) backup film cooler, (3) seal pot, and (4) two borescope cameras. From the off-gas flammability standpoint, the air purge to the primary film cooler is used strictly as dilution air, since the gas temperature inside the film cooler is too low for combustion. The remaining air purges are used as both combustion and dilution air. An additional air purge is provided to control the melter pressure. However, the pressure control air is not counted as a dilution source in the flammability calculations, since it can vary widely during a transient depending on the degree of fluctuations in melter pressure.

As shown in Figure 1, the total air purge to the melter system is controlled by FIC3221A, and the air purge to the backup film cooler by FIC3221B. The air purges to the borescope cameras are set at constant flows using restriction orifices; RO3226, RO3227, RO3228 and RO3231. Each orifice restricts the air flow at $30 \mathrm{lb} / \mathrm{hr}$ for a total of $120 \mathrm{lb} / \mathrm{hr}$ to the borescope cameras. However, $1 / 2$ of this borescope camera air is purged back out to the cell, and only the remaining $60 \mathrm{lb} / \mathrm{hr}$ or $30 \mathrm{lb} / \mathrm{hr}$ to each camera lens ends up in the melter vapor space. The 
air purge to the seal pot is maintained at $20 \mathrm{lb} / \mathrm{hr}$ using RO3230. Currently, the set points for FIC3221A and FIC3221B are 1,070 and $340 \mathrm{lb} / \mathrm{hr}$, respectively, during normal operation. Figure 1 shows that at these set points the air purges actually delivered to the primary and backup film coolers are 560 and $370 \mathrm{lb} / \mathrm{hr}$, respectively, including a line purge at $30 \mathrm{lb} / \mathrm{hr}$ each through RO3236 and RO3237. The total air purge into the vapor space is $450 \mathrm{lb} / \mathrm{hr}$ $(=370+20+30+30)$, which is nearly twice the required minimum combustion air for the SB3 feed.

\subsection{Air Purge Scenarios}

A total of 9 different air purge scenarios were considered, including the normal operation shown in Figure 1 (Case 1), to check if the total air purge into the vapor space would at least equal the required minimum $230 \mathrm{lb} / \mathrm{hr}$ under all operating modes. Those cases considered were devised by varying the melter operating mode from normal to seismic, the air supply mode from normal to minimum, and the number of borescope cameras in use from 0 to 2 . Figures 1 through 9 show the air flow rates through various melter components for each of those 9 cases (note that the figure number also corresponds to the case number). A brief discussion of the results for each case is given next.

The operating conditions for Case 2 are identical to those of Case 1 except that only the East borescope camera is operational, and the air purge to the West borescope camera has been discontinued by shutting off the valves, PLA3228-1 and 3226-1 (see Figure 2). As a result, compared to Case 1, the total air purge into the vapor space is reduced from 450 to $420 \mathrm{lb} / \mathrm{hr}$, and a total of $60 \mathrm{lb} / \mathrm{hr}$ of air is diverted to the primary film cooler, thus increasing the dilution air purge from 560 to $620 \mathrm{lb} / \mathrm{hr}$.

The operating conditions for Case 3 are identical to those of Case 1 except that the air purge to both borescope cameras has been discontinued by shutting off PLA3227-1, 3223-1, 3228-1 and 3226-1 (see Figure 3). As a result, compared to Case 2, the total air purge into the vapor space is reduced by an additional $30 \mathrm{lb} / \mathrm{hr}$ to $390 \mathrm{lb} / \mathrm{hr}$, and an additional $60 \mathrm{lb} / \mathrm{hr}$ of air is diverted to the primary film cooler, thus increasing the dilution air purge to $680 \mathrm{lb} / \mathrm{hr}$.

Cases 4 to 6 involve normal melter operation but at the minimum total melter air purge (FIC3221A) and the minimum backup film cooler air purge (FIC3221B), which are currently set at 900 and $233 \mathrm{lb} / \mathrm{hr}$, respectively. The actual feed interlock set points for FIC3221A and FIC3221B are set somewhat higher than these theoretical minima, since safety margins have to be added to account for various uncertainties. Figure 4 shows that with both borescope cameras in operation the total air purge into the melter vapor space under the feed interlock conditions is $343 \mathrm{lb} / \mathrm{hr}(=263+20+30+30)$, or 1.5 times the required minimum. The remaining $497 \mathrm{lb} / \mathrm{hr}$ (=900-343-30-30) is delivered to the primary film cooler to cool and dilute the offgas exiting the melter. Figures 5 and 6 show the corresponding air flows when one and no borescope camera is in operation, respectively. As in Cases 2 and 3, with each reduction in the number of borescope cameras in use, the total air purge into the vapor space is reduced by $30 \mathrm{lb} / \mathrm{hr}$, and the dilution air purge is increased by $60 \mathrm{lb} / \mathrm{hr}$. The resulting total air purge into the vapor space for Case 6 is $283 \mathrm{lb} / \mathrm{hr}(=263+20)$, which is still $23 \%$ above the required minimum combustion air. 
The operating conditions for Cases 7 to 9 are identical to those of Cases 4 to 6 , respectively, except that the melter is now operated under the seismic conditions. The maximum leakage rates from the DWPF melter air purge lines were estimated in the event of a design basis earthquake (DBE). ${ }^{14,15}$ Based on the assumption that leakages would occur in the pipes downstream of each of the three restricting orifices (RO3230, RO3231, and RO3226) and in the two jumpers connecting to the primary and backup film coolers, calculations showed that the maximum leakage rate would be $33 \mathrm{lb} / \mathrm{hr}$ at each location or $165 \mathrm{lb} / \mathrm{hr}$ total. ${ }^{14,15}$ Figure 7 shows that during a postulated DBE with both borescope cameras in operation the total air purge into the vapor space under the feed interlock conditions is $230 \mathrm{lb} / \mathrm{hr}$, which is right at the required minimum. The remaining $445 \mathrm{lb} / \mathrm{hr}$ (=900-230-165-30-30) is then delivered to the primary film cooler. Figures 8 and 9 show that regardless of the number of borescope cameras in operation the total air purge into the vapor space remains the same as the required minimum of $230 \mathrm{lb} / \mathrm{hr}$, since the air purges to both the borescope cameras and the seal pot are presumed to be lost during a DBE. 


\subsection{CONCLUSIONS}

The total air flows for combustion and dilution discussed so far are summarized in Table 2 for all 9 cases. It is clearly shown that the minimum combustion air requirement was met in all 9 cases. So, there is no potential for the system ever becoming deficient of combustion air. It is further noted that as the number of borescope cameras in operation was decreased, the total combustion air flow was decreased or remained at the required minimum, while the total dilution air flow was increased. It is, therefore, concluded that complete removal of borescope camera air purge will actually improve the combustion efficiency and lower the potential for off-gas flammability downstream of the melter. As a result, there is no need for the revision of the existing E-7 calculations that were used to set the current operating limits for the DWPF melter.

Table 2. Effects of Melter Operation and Borescope Camera Air Purge on Combustion and Dilution Air Flows.

\begin{tabular}{|c|c|c|c|c|c||}
\hline Case & $\begin{array}{c}\text { Mode of } \\
\text { Operation }\end{array}$ & $\begin{array}{c}\text { Mode of } \\
\text { Air Purge }\end{array}$ & $\begin{array}{c}\text { No. of } \\
\text { Borescope } \\
\text { Cameras in Use }\end{array}$ & $\begin{array}{c}\text { Total } \\
\text { Combustion Air } \\
(\mathrm{lb} / \mathrm{hr})\end{array}$ & $\begin{array}{c}\text { Total } \\
\text { Dilution Air } \\
(\mathrm{lb} / \mathrm{hr})\end{array}$ \\
\hline 1 & Normal & Normal & 2 & 450 & 560 \\
\hline 2 & " & " & 1 & 420 & 620 \\
\hline 3 & " & " & 0 & 390 & 680 \\
\hline 4 & " & Minimum & 2 & 343 & 497 \\
\hline 5 & " & " & 1 & 313 & 557 \\
\hline 6 & " & 0 & 283 & 617 \\
\hline 7 & Seismic & " & 2 & 230 & 445 \\
\hline 8 & " & & 1 & 230 & 508 \\
\hline 9 & & & 0 & 230 & 571 \\
\hline
\end{tabular}




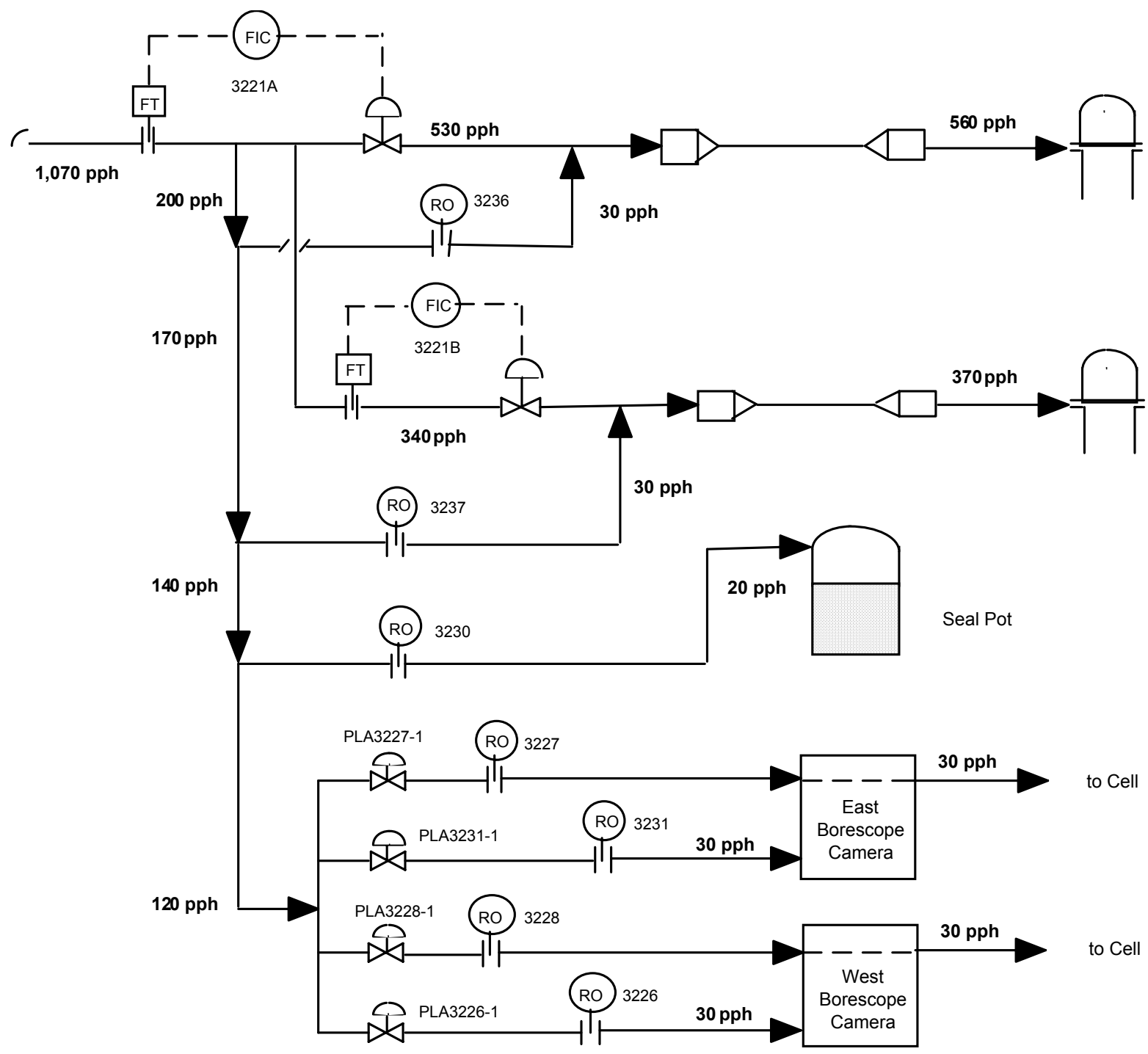

Figure 1. Baseline DWPF Melter Air Purges during Normal Operation with Two Borescope Cameras. 
WSRC-TR-2004-00008

Revision 0

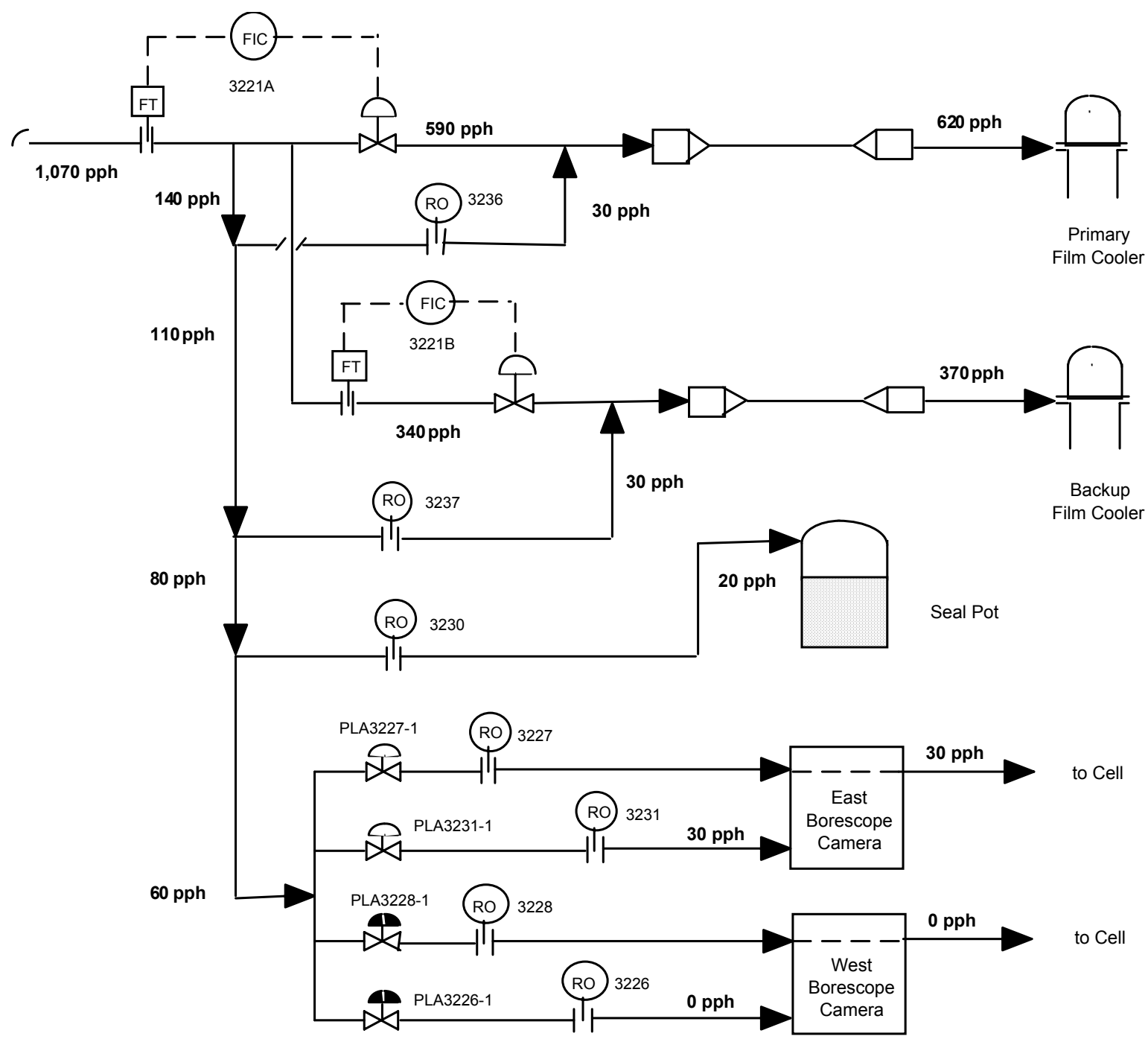

Figure 2. DWPF Melter Air Purges during Normal Operation with One Borescope Camera. 


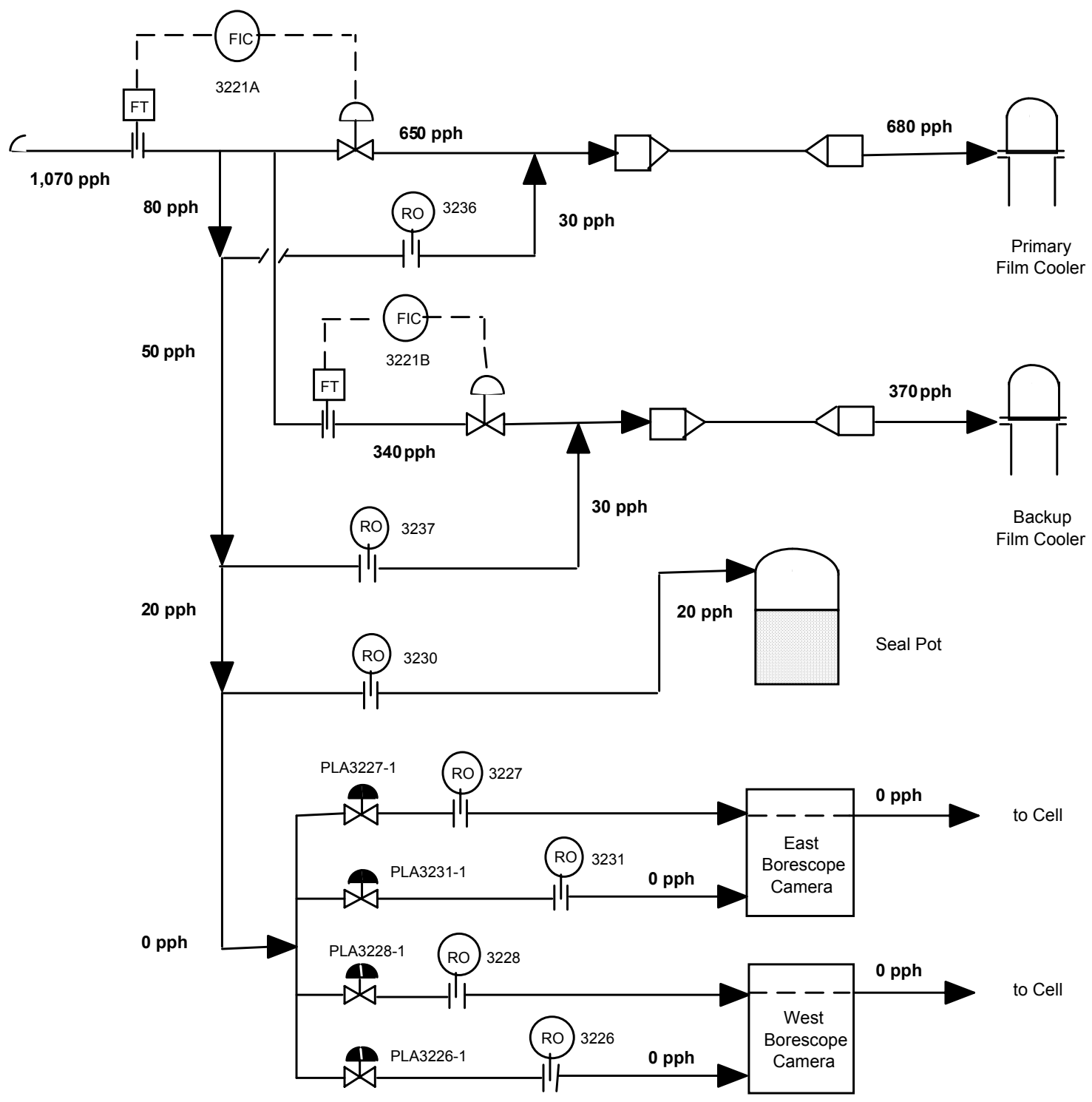

Figure 3. DWPF Melter Air Purges during Normal Operation with No Borescope Camera. 


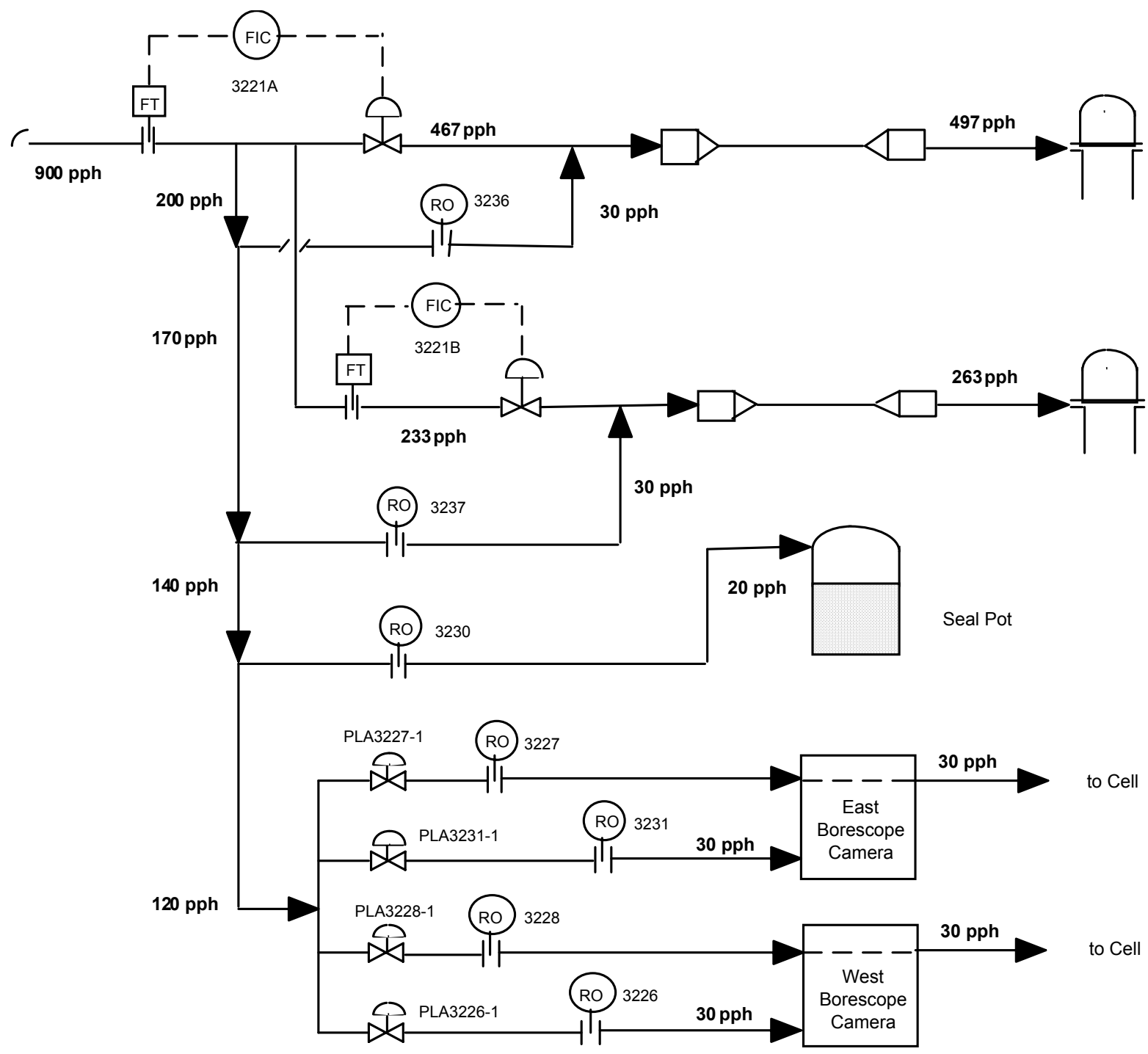

Figure 4. Minimum DWPF Melter Air Purges during Normal Operation with Two Borescope Cameras. 
WSRC-TR-2004-00008

Revision 0

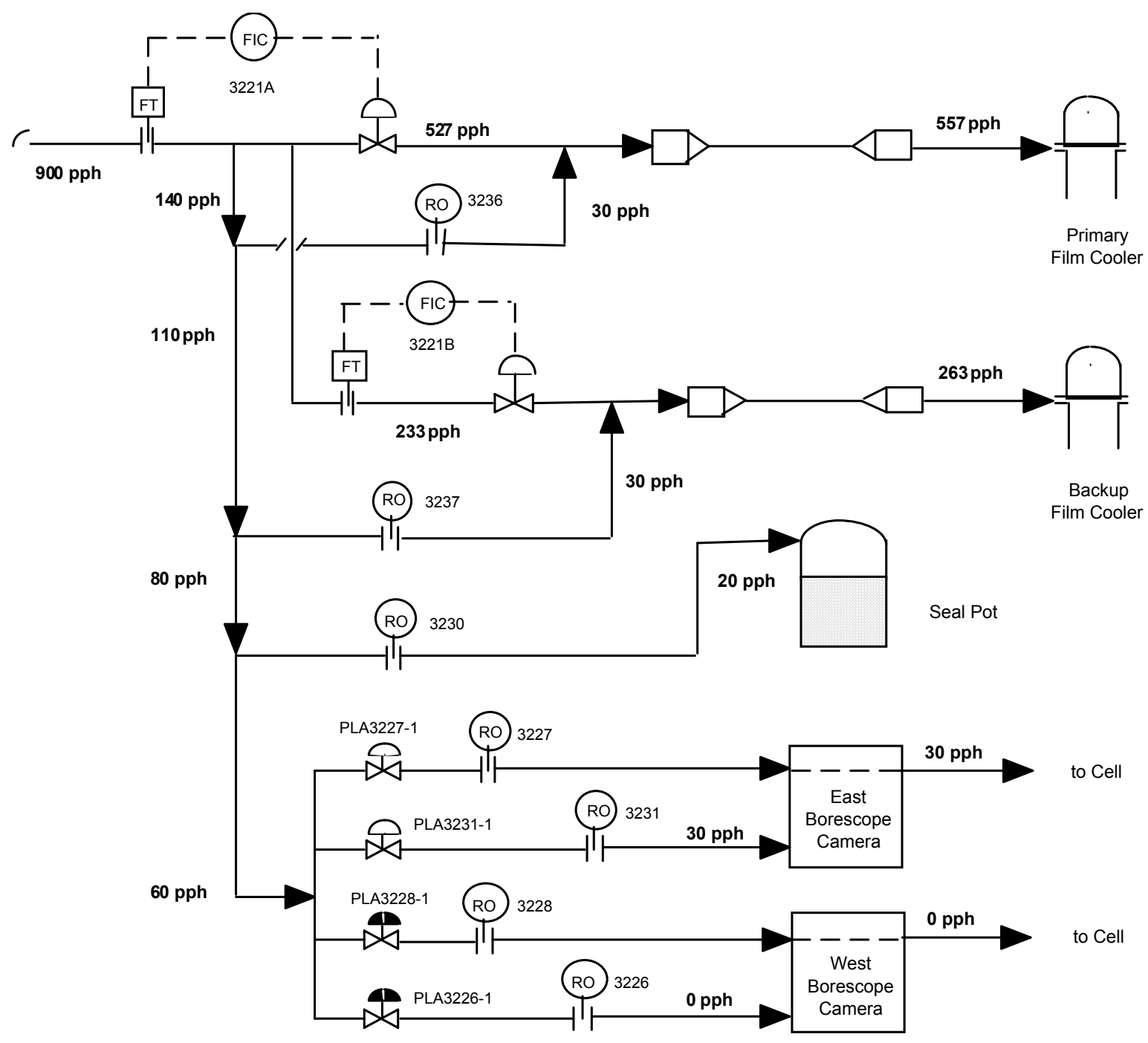

Figure 5. Minimum DWPF Melter Air Purges during Normal Operation with One Borescope Camera. 
WSRC-TR-2004-00008

Revision 0

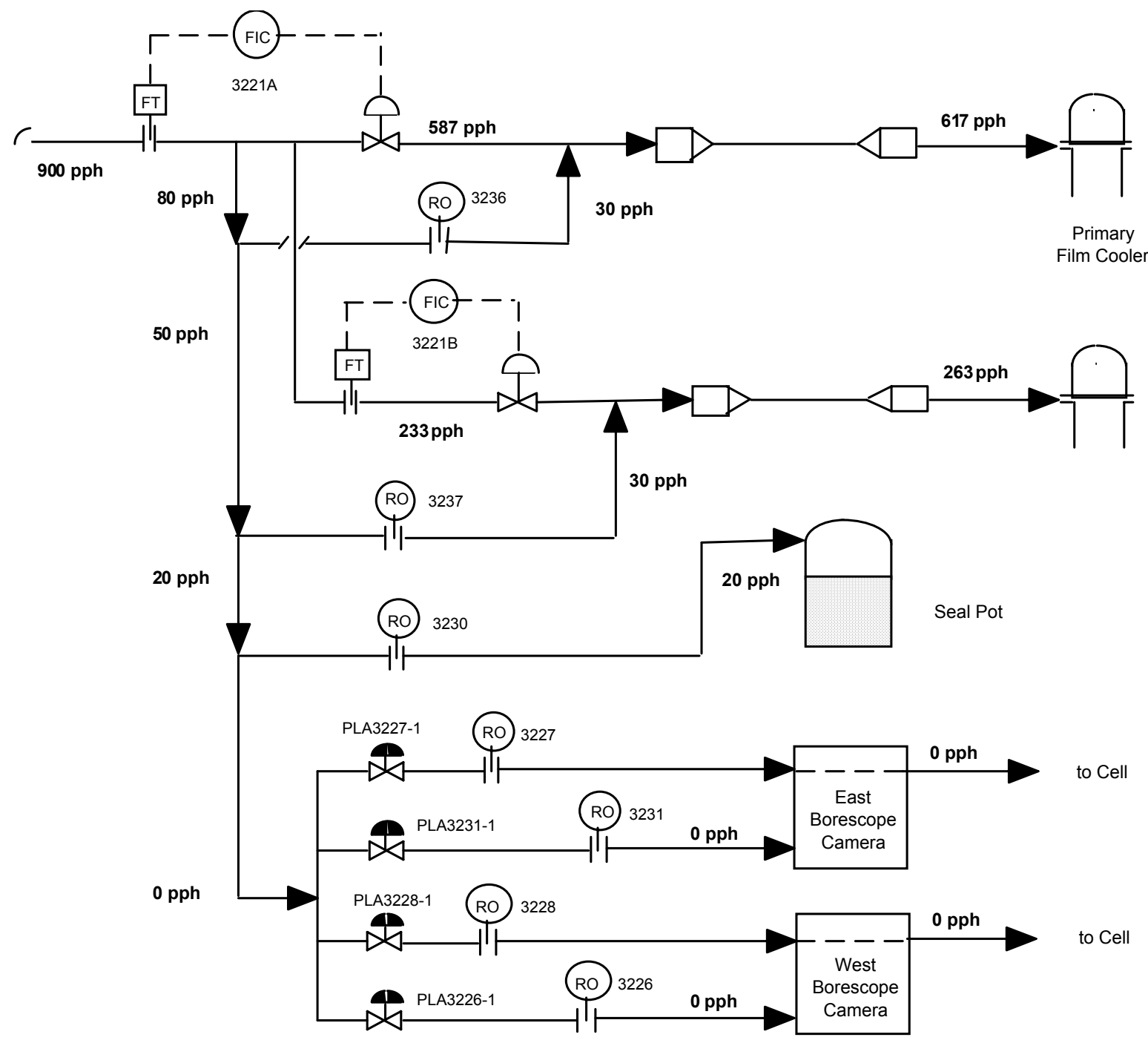

Figure 6. Minimum DWPF Melter Air Purges during Normal Operation with No Borescope Camera. 


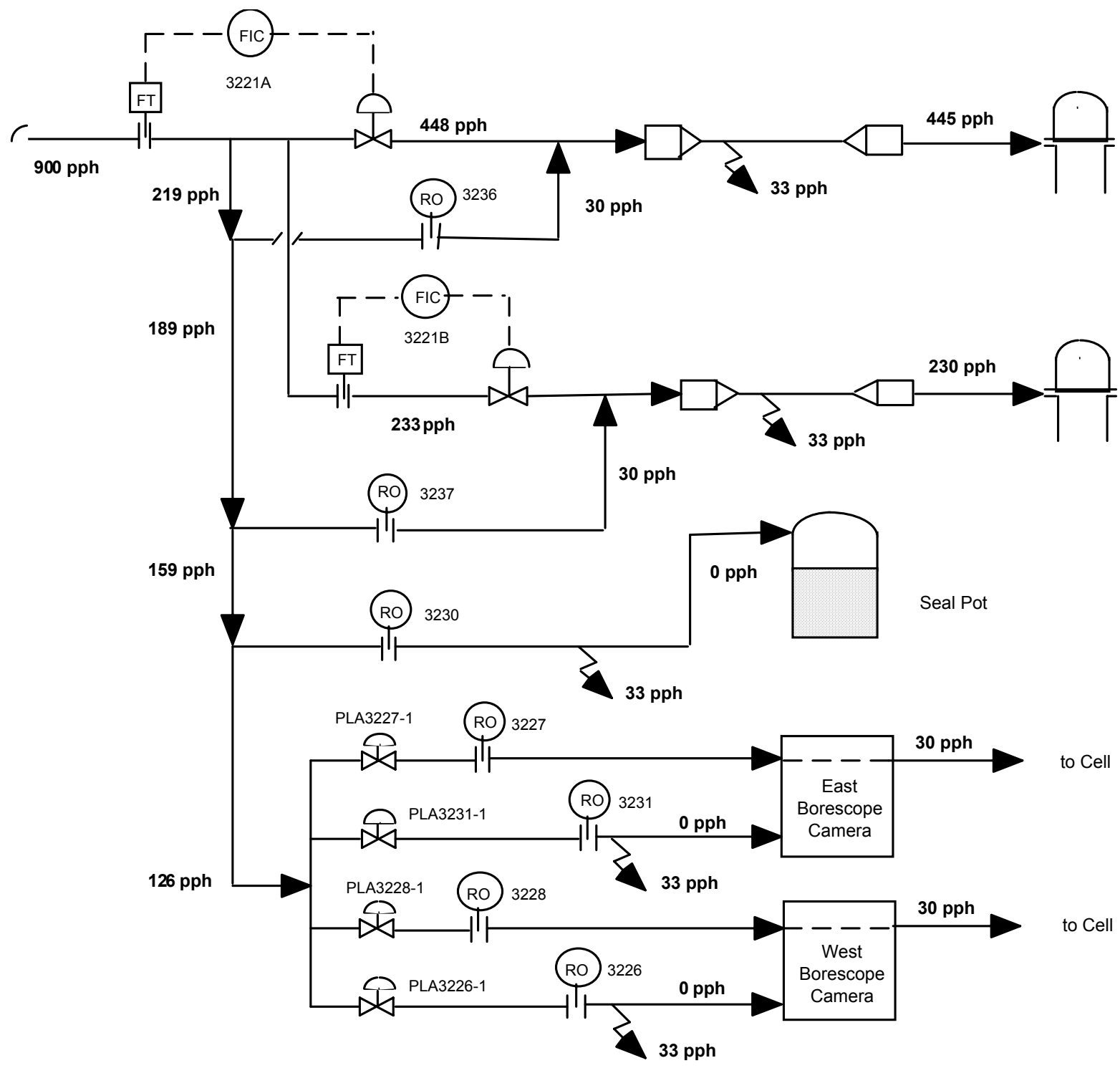

Figure 7. Minimum DWPF Melter Air Purges during Seismic Operation with Two Borescope Cameras. 


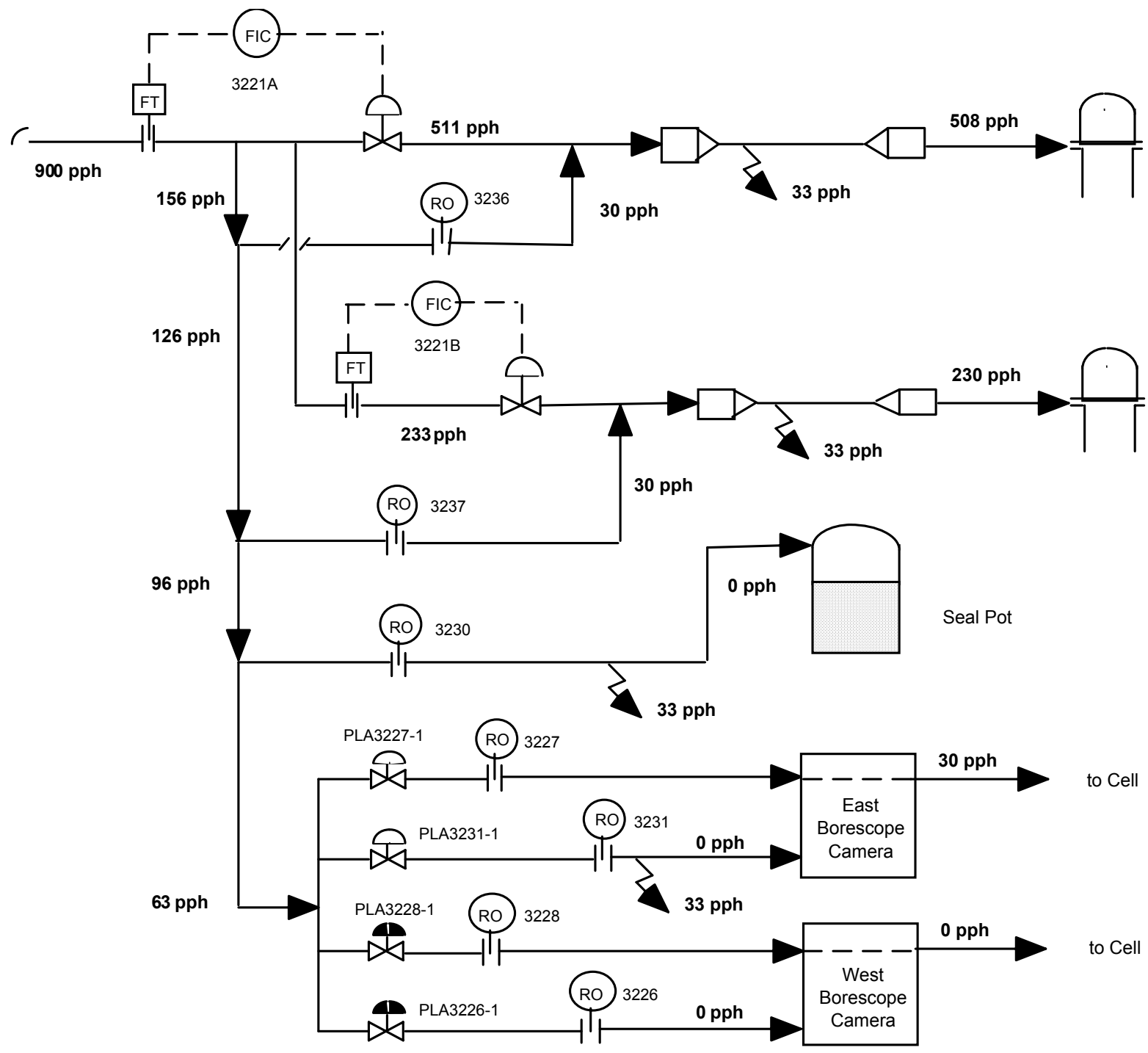

Figure 8. Minimum DWPF Melter Air Purges during Seismic Operation with One Borescope Camera. 


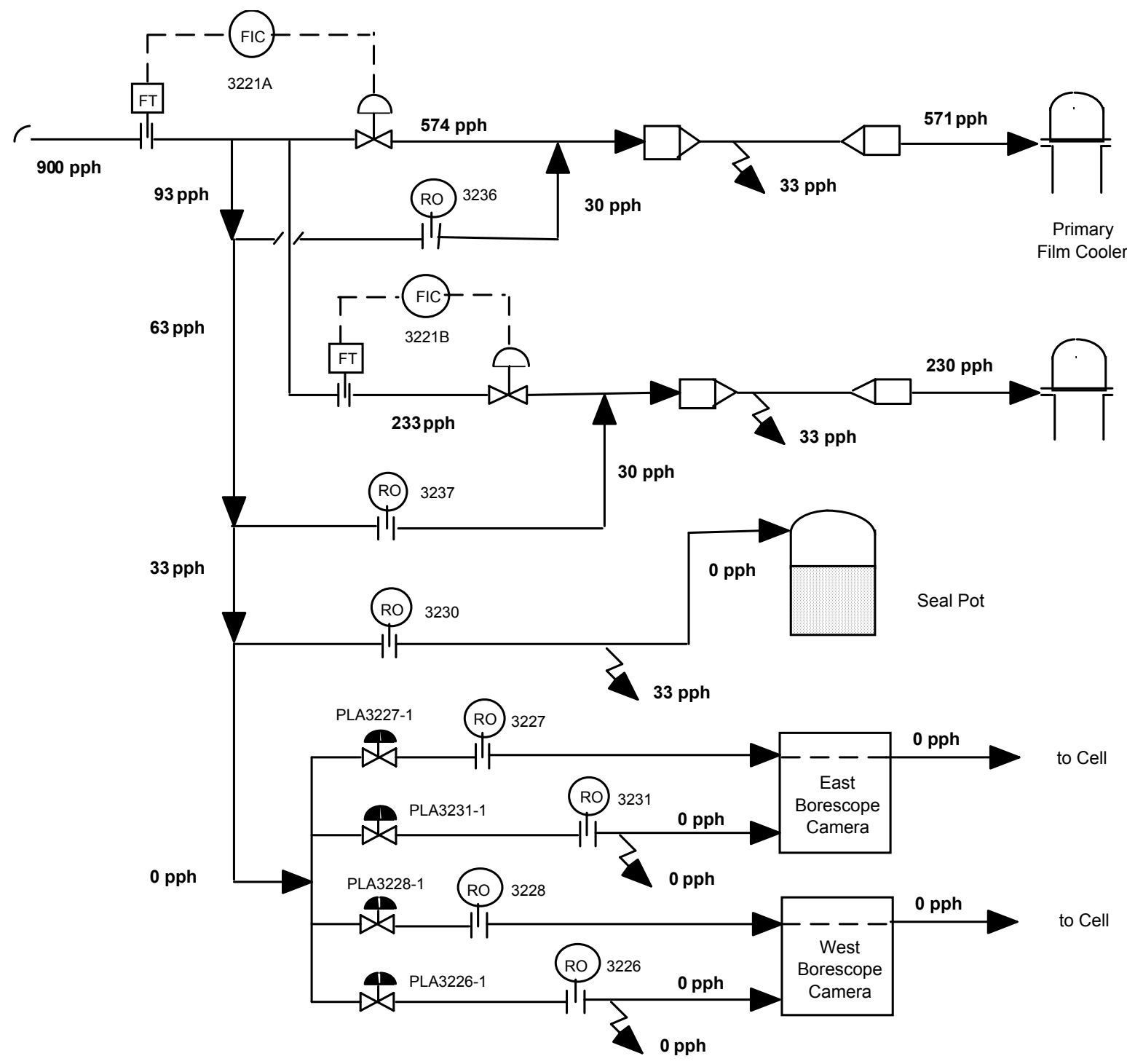

Figure 9. Minimum DWPF Melter Air Purges during Seismic Operation with No Borescope Camera. 


\subsection{REFERENCES}

1. Choi, A. S., "Validation of DWPF Melter Off-Gas Combustion Model," WSRC-TR-2000-00100, June 23, 2000.

2. Choi, A. S., "Validation of DWPF MOG Dynamics Model - Phase I (U)," WSRC-TR-96-0307, January 7, 1997.

3. Hull, H. L., "Trip Report Battelle-Pacific Northwest Laboratory Slurry-Fed Melter Test May 17-21, 1982," DPST-82-718, July 20, 1982.

4. Randall, C. T., and Colven, W. P., "Off-Gas Flow Surges from the Slurry Fed Melter," DPST-82-966, November 1, 1982.

5. Basic Data Report, DPSP-80-1033, Volume 1, April 1985.

6. Choi, A. S., "DWPF Melter Off-Gas Flammability Assessment for Sludge Batch 3," X-CLC-S-00124, Rev. 1, February 24, 2002.

7. Choi, A. S., "Steady State Indicated Temperature of DWPF Melter Vapor Space at 1.5 GPM Feed Rate," X-CLC-S-00096, September 1, 2000.

8. Choi, A. S., "Minimum Air Flow for the DWPF Melter Backup Film Cooler (U)," WSRC-TR-92-376, July 31, 1992.

9. Choi, A. S., "Impact of Lower Vapor Space Temperature on DWPF Melter Off-Gas Flammability during Sludge-Only Operation," X-CLC-S-00097, Rev. 1, April 23, 2001.

10. Buch, V. R., Technical Task Request, HLW/DWPF/TTR-03-0015, Rev. 0, September 3, 2003.

11. Choi, A. S., "Maximum Total Organic Carbon Limits at Different DWPF Melter Feed (U)," WSRC-TR-95-0119, Rev. 0, March 13, 1995.

12. Choi, A. S., "DWPF Melter Off-Gas Flammability Calculations for Coupled Feed Flowsheet,” X-CLC-S-00081, Rev. 0, May 27, 1997.

13. Choi, A. S., Rabon, G. F., Smith, M. E., Goudelock, S. L., Crow, K. R., Wehner, A. M., and Baron, M. R., "Summary of Campaigns SGM-9 and SGM-10 of the DWPF Scale Glass Melter (U),” DPST-88-626, December 15, 1988.

14. Julian, P., "Melter Off-Gas Film Cooler Leakage Rates (U)," M-CLC-S-00666, February 20, 1998.

15. Julian, P., "Maximum Flow Rates Though Orifices RO-3226, RO-3231, and RO-3230 (U)," M-CLC-S-00667, February 23, 1998. 